\title{
FOREIGN POLICY, \\ THE SILENT MAJORITY AND CONGRESS
}

WORLDVIEW is published monthly [except for a combined July-August issue] by the Council on: Religion and International Af. fairs. Subscription $\$ 4.00$ for one year; $\$ 7.00$ for two years; $\$ 9.00$ for three years.

Address: 170 East 64th Street, New York, New York 10021. TE 8-4120

\section{EDITORIAL BOARD \\ James Finn: Editor John R. Inman \\ A. Williem Loos \\ Editorial Assistants: \\ Susan Woolfson \\ Kip Zegers}

Contributing Editors: Danald Brandon, Jerald C. Brauer, Emest W. Lefever, Bernard Murchlarid, Edmund Stillman

\section{CONTENTS}

In the Magazines

Foreign Pollcy, Congress and the Silent Majority Editorial

The Perils of Reform Intervention Ernest W. Lefever

Political Theory and Clerical

Radicalism

Robert A. Monson

Acheson, Present at the Creation, Now Reports Donald Brandon

Social Ethical Decision-Making in the '70's Other Voices

"In Defense of Defense" Correspondence

Books

Rx for Existential Nausea Monika Hellwig

Current Reading

Roader are reminded that worldviow waicomes correspondence. Lettors mey be secific com. mente on erticlos in recent fosues of meneral dis. cussion but reeders are raquated to limit their letters to 500 words

Opintons expresced in worldviow ere those of the uthors, and not necessurily of the councll on 1970 Council on Religlon and International Affairs.
Interventionism or isolationism. These are the terms in which, supposedly, the future of United States foreign policy is to be debated. It is, of course, as impossible for the United States to withdraw completely into a fortress as it is for the United States to intervene in every area in which it has some interest. The terms must be understood only as indicating directions any country might take, within the limits of its resources. Will the U.S. be more or less interventionary in the coming decades than it has been in the last several decades? More or less isolationist?

The war in Vietnam has clearly been a traumatic experience for the American people and it is natural to. wonder how they will react when they emerge from that trauma. The Manchester Guardian, not always sympathetic to foreign policies of the United States, is now concerned that the U.S. will lean in the wrong dircction. After recalling the exuberance of the Kennedy years, when so many things seemed possible if only America had the will to act, the Guardian said:

"Those who have survived [Kennedy] have learned since then that the world is a grayer place: in South America, where Kennedy's Alliance for Progress is part engulfed in tyrannies other than communism; in Vietnam, where the supposed whites keep turning gray; in Southern Africa, where capitalism has proved no guarantee of human freedom or decency; in Greece, where the ideals for which President Truman and Ernest Bevin founded the North Atlantic Treaty organization have been betrayed. But Czechoslovakia has shown that Kennedy's Communist tiger has not shed its stripes either, and that also has been a lesson from Vietnam."

In the world of foreign policies, grayness abounds, no doubt. The rhetoric of "free world" and "Communist world"so often made to serve as counters for intellectual analyses - has faded almost into disuse, and less appealing, more complex discriminations are called for. And in spite of continual, sharp confrontations in the domestic life of America, in spite of a great deal of free-floating resentment and hostility, a depressing grayness hovers over much of our domestic politics. There is an uncertainty, not to say distrust, of our political leaders.

There is some reason, then, for the Guardian to wonder if, after Vietnam, the United States will draw in upon itself, if it will withdraw its troops from Europe, if it will resolve not to

February $1970 \quad 3$ 
fight another land war in Asia, if it will channel its aid away from the Third World to the ghettoes of its inner cities. There is some reason for this journal to conclude:

"These are dangers that the world should acknowledge as it enjoys the spectacle of the richest and most successful nation bloodying its nose at home and abroad. No British post-imperial sourness, no Western European envy, no Afro-Asian ambivalence about systems of government would excuse a world hostility that drove the United States into its prewar isolation."

On the basis of official statements, rather than on our own readings of the situation, in what direction is the United States tending? William P. Rogers, Secretary of State, gave the most succinct answer to this question when, speaking to the editors of U.S. News and World Report, he said:

"Our general posture today is one of a lowered profile and a reduced presence of the United States, consistent with security considerations. This includes speaking with a lower voice, as the President said in his inaugural address, and generally facing up to the realities of the world situation as they exist today.

"In carrying out this general change of posture, the President announced at Guam a new policy approach which means that the United States is not going to be involved in active belligerency in situations of insurgency. This means that our troop strength in some areas of the world will be reduced, as it has been in Vietnam and in Thailand. It means putting more emphasis on regional cooperation, making other nations realize that they have to take the lead in carrying out the responsibilities in their area."

-

If this is coupled with the official statements that a smaller proportion of our national income is to be devoted to military expenditures, then one should be able to infer the general direction in which the United States is moving-it will be less interventionist than it has been; it will not attempt to police the world. But the United States is simply too powerful, with interests and obligations too far-reaching, for it to withdraw from the world. It is no more fashioned for pre-war isolationism than Mae West for a Trappist monastery. What the U.S. is doing, according to Secretary Rogers, is to shape "our foreign policy in a way that is consistent with our present-day realities and in a way that's consistent with our national sesources."
The balanced statements of Secretary Rogers are welcome. But they do lead to the inevitable questions: what are present-day realities? what is consistent with our national resources? where lies the greatest responsibility for making these judgments? In an article elsewhere in this issue Ernest Lefever writes that "the great majority of the American people .... reject the ideology and selfrighteousness of the reform interventionists, the do-good imperialists, who want to impose their virtue on others with the help of the U.S. Government and with little regard for U.S. security interests." And again, "Who are we to tell the Greeks or the Brazilians, or the Israelis or the Egyptians for that matter, what kind of government they should have? Where is our cherished doctrine of self-determination?"

If this assessment is correct then the great majority must sit in heavy judgment on John Foster Dulles who condemned neutralism as immoral and who, with mixed success, told the leaders of a number of countries what their policies should be. And also on those who planned and carried out recent policies in the Dominican Republic, and Cuba. And Vietnam? As was noted by the National Policy Panel of the United Nations Association, under the chairmanship of Arthur J. Goldberg, the war in Vietnam "was initiated and continues in violation of the tradition of demo. cratic consent that is central to government in a free society." For we did not, when that war was initiated, attempt to ascertain what the popullar will of the nation was. Nor, putting aside the various opinion polls, have we yet attempted to do so.

To put the matter bluntly, in foreign affairs the executive has usturped powers traditionally assigned to Congress, most notably the power to wage war. And in time of war, the United States - - like all democratic states-becomes less democratic. The silent majority, by the mere fact of being silent, goes along. But in these conditions, to be skeptical of the claims of the dissenters on the grounds that they are a minority is to be essentially frivolous. If, in matters of foreign policy, one wishes to preserve both the sitbstance and the form of democracy, new political structures and procedures must be devised. This is the path suggested by the National Policy Panel of the U.N.A. The other is to follow the experts and claim the support of the silent majority.

J.F. 